\title{
Repellent Activity of Essential Oil from Tulsi Plant against Lesser Grain Borer, Rhyzopertha dominica (Fabricius) (Coleoptera: Bostrichidae) and Red Rust Flour Beetle, Tribolium castaneum Herbst, (Coleoptera: Tenebronidae)
}

\author{
Joshi Rashmi* and Gaur Neeta \\ Department of Entomology, College of Agriculture, GBPUA\&T, Pantnagar, \\ Uttarakhand, India \\ *Corresponding author
}

\section{A B S T R A C T}

Keywords

Repellency, Tulsi oil, Rhyzopertha

dominica, Tribolium

castaneum

Article Info

Accepted:

04 January 2018

Available Online:

10 February 2018
Essential oil of Tulsi was investigated for repellent activity against two stored grain insect pests, Rhyzopertha dominica and Tribolium castaneum. The ethanolic concentrations of oil at $1 \%, 2 \%$ and $3 \%$ were tested. It was found that repellent activity was proportional to the concentration and higher concentration has stronger effect. Moreover the repellent effect was better on $T$. castaneum as compared to $R$. dominica. $T$. castaneum showed 95.96, 98.69 and $99.56 \%$ repellent activity at 1,2 and $3 \%$ concentration of essential oil respectively. Hence, botanical insecticides might be used as an alternative for grain protection against stored grain insect-pests.

\section{Introduction}

Insects are amongst major pests of cereals and they often cause an important economical damage that amount to $5-10 \%$ in the temperate zone and to 20-30\% in the tropical one (Haque et al., 2000). R. dominica and $T$. castaneum are one of the major pests of stored grains. However, these insecticides are often associated with residues that are dangerous for the consumer and the environment (Lamiri et al., 2001). Therefore, there is an interest in finding alternative way for stored product protection, especially within the scope of natural products that are known to be useful and non-toxic for human health and environment.

Bio- insecticides based on the plant essential oils may represent an alternative to traditional insecticide. Plant extracts contain compounds that show ovicidal, repellent, antifeedant, sterilization and toxic effects in insects (Nawrot and Harmatha, 1994; Isman, 2006). 
Plants in the family Lamiaceae are aromatic herbs with enormous socio-economic value in flavouring, cosmetics and perfumery, confectionary and medicinal preparations (Magness et al., 2006).The present study was therefore undertaken to evaluate the activity of Tulsi oil against $R$. dominica and $T$. castaneum.

\section{Materials and Methods}

\section{Essential oil}

Oils selected for the study were extracted from the locally available plants by steam distillation at Medicinal and Aromatic Plants Research and Development Centre, Pantnagar.

\section{Method for repellency test}

Repellency test was conducted following the method of Talukdar and Howse (1993). Petri dishes $9 \mathrm{~cm}$ in diameter were used to confine insects during experiment. The essential oils were diluted in ethanol to different concentrations $(1.0 \%, 2.0 \%$ and $3.0 \%)$ and absolute ethanol was used as control. Filter paper with a $9 \mathrm{~cm}$ diameter was cut in half and $1 \mathrm{ml}$ of each concentration was applied separately to one half of the filter paper as uniformly as possible with a micropipette. Another half (control) was treated with $1 \mathrm{ml}$ of absolute ethanol. Both the treated half and the control half were then air dried to evaporate the solvent completely. A full disc was carefully remade by attaching the treated half to the control half with tape. Care was taken so that the attachment did not prevent free movement of insects from the one half to another, but the distance between the filter paper halves remained sufficient to prevent diffusion of test sample from one half to another. Each remade filter paper was placed in a petri dish. Twenty insects were released in the centre of each filter paper disc and cover was placed over the petri dish. Three replicates were used and experiment was repeated twice. Counts of the insects present on each half were made after every half an hour and up to fifth interval. Percent repellency of each oil was calculated by using the following formula from Abbott (1925):

Percent Repellency $=$ A - B

A

Here,

$\mathrm{A}=$ Average number of insects present on untreated portion

$\mathrm{B}=$ Average Number of insects present on treated portion

\section{Results and Discussion}

\section{Repellent activity of tulsi oil against $R$. dominica}

Among the tested concentrations highest repellency was observed in 3\% concentration of essential oil i.e. 98.20 (Table 1), $R$. dominica at $2 \%$ and $3 \%$ showed less repellent activity as compared to $3 \%$ i.e. 90.06 and 98.20 , respectively.

\section{Repellent activity of tulsi oil against $T$. castaneum}

All the tested concentrations against $T$. castaneum showed good results (Table 2) and 95.96, 98.69 and 99.56 percent repellency was observed at $1 \%, 2 \%$ and $3 \%$ respectively. 
The percentages of repellency were then categorized according to the following scale by the method of Roy et al., (2005)

\begin{tabular}{|c|}
\hline Class \\
\hline 0 \\
\hline I \\
\hline II \\
\hline III \\
\hline IV \\
\hline V \\
\hline
\end{tabular}

\begin{tabular}{|c|}
\hline Repellency Rate $(\%)$ \\
\hline
\end{tabular}

Table.1 Repellency of Tulsi oil against $R$. dominica

\begin{tabular}{|c|c|c|c|c|c|c|}
\hline \multirow[t]{2}{*}{ Concentration } & \multicolumn{4}{|c|}{ Percent repellency of Tulsi oil against $R$. dominica } & \multirow{2}{*}{$\begin{array}{l}\text { Mean } \\
\text { repellency }\end{array}$} & \multirow{2}{*}{$\begin{array}{l}\text { Repellency } \\
\text { class }\end{array}$} \\
\hline & $30 \mathrm{~min}$ & $60 \mathrm{~min}$ & $90 \mathrm{~min}$ & $120 \mathrm{~min}$ & & \\
\hline $1 \%$ & 77.12 & 90.83 & 92.79 & 92.79 & 88.38 & $\mathrm{~V}$ \\
\hline $2 \%$ & 84.03 & 88.66 & 92.79 & 94.74 & 90.06 & V \\
\hline $3 \%$ & 94.54 & 98.25 & 100.00 & 100.00 & 98.20 & V \\
\hline
\end{tabular}

Table.2 Repellency of Tulsi oil against $T$. castaneum

\begin{tabular}{|c|c|c|c|c|c|c|}
\hline \multirow{2}{*}{ Concentration } & \multicolumn{4}{|c|}{ Percent repellency of Tulsi oil against $T$. castaneum } & \multirow{2}{*}{$\begin{array}{l}\text { Mean } \\
\text { repellency }\end{array}$} & \multirow{2}{*}{$\begin{array}{l}\text { Repellency } \\
\text { class }\end{array}$} \\
\hline & $30 \mathrm{~min}$ & $60 \mathrm{~min}$ & $90 \mathrm{~min}$ & $120 \mathrm{~min}$ & & \\
\hline $1 \%$ & 92.59 & 98.25 & 96.49 & 96.49 & 95.96 & V \\
\hline $2 \%$ & 100.00 & 98.25 & 98.25 & 98.25 & 98.69 & V \\
\hline $3 \%$ & 100.00 & 100.00 & 98.25 & 100.00 & 99.56 & V \\
\hline
\end{tabular}

The results of the above two studies indicate that the plant essential oils are as effective as chemical grain protectants for protection of grains.

\section{References}

Abbott, W.S. 1925. A method of computing the effectiveness of an insecticide. $J$. Econ. Entomol., 18, 266-267.

Haque, M. A., Nakakita H., Ikenaga, H. and Sota, N. 2000. Development inhibiting activity of some tropical plants against
Sitophilus zeamais Motschulsky (Coleoptera Curculionidae). J. Stored Prod. Res., 36, 281-287

Isman, M.B. 2006. Botanical insecticides, deterrents, and repellents in modern agriculture and an increasingly regulated world. Annual Review of Entomology, 51, 45-66.

Lamiri, A.; Lhaloui, S.; Benjilali, B. and Berrada, M. 2001. Insecticidal effects of essential oils against hessian fly, Mayetiola destructor (Say). Field Crop Res., 71, 9-15

Nawrot, J. and Harmatha, J. 1994. Natural 
products as antifeedants against stored product insects. Post Harvest News and Information, $5,17 \mathrm{~N}-21 \mathrm{~N}$.

Roy, B.; Amin, R. and Uddin, M.N. 2005. Leaf extracts of Shiyalmutra (Blumea lacera) as botanical insecticides against lesser grain borer and riceweevil. $J$. Biol. Sci., 5, 201-204.
Talukdar, F.A. and Howse, P.E. 1993. Deterrent and insecticidal effect of extract of pithraj, Aphanamixis polystacha against Tribolium castaneum. J. Chem. Ecel., 19, 24632471.

\section{How to cite this article:}

Joshi Rashmi and Gaur Neeta. 2018. Repellent Activity of Essential Oil from Tulsi Plant against Lesser Grain Borer, Rhyzopertha dominica (Fabricius) (Coleoptera: Bostrichidae) and Red Rust Flour Beetle, Tribolium castaneum Herbst, (Coleoptera: Tenebronidae). Int.J.Curr.Microbiol.App.Sci. 7(02): 157-160. doi: https://doi.org/10.20546/ijcmas.2018.702.020 